\title{
Sfântul Maxim Mărturisitorul despre gen, căsătorie și sfințenie (Ambigua 10 și 41)
}

\section{Doru COSTACHE*}

\author{
In memoria lui Paul Evdokimov, \\ teologul mistagogiei nupțiale ortodoxe, \\ la împlinirea a cincizeci de ani \\ de la trecerea sa la Domnul
}

Abstract: St Maximus the Confessor on Gender, Marriage and Holiness in Amb. 10 and 41. This article analyses and interprets three passages from Saint Maximus the Confessor's Ambigua (The Book of Difficulties) that touch upon matters of gender, sexuality, and the connubial life. My contention is that he construed holiness as achievable by celibate people, monastics, and married couples alike. To affirm conjugal life as a form of holy life, he deployed a logic that anticipates Paul Evdokimov's concept of "interiorised monasticism".

Keywords: ascesis, celibacy, gender, holiness, marriage, monasticism, sexuality, virtue.

De la jumătatea secolului trecut încoace, cercetători precum Cooper, Balthasar și Thunberg, spre a-i aminti doar pe aceştia, au evidențiat existența unor interesante perspective despre gen, căsătorie, sexualitate și sfințenie în scrierile Sfântului Maxim Mărturisitorul (m.

* Lector Senior și îndrumător de doctorate în cadrul Școlii Doctorale la Sydney College of Divinity, Australia. Asociat de Onoare al Departamentului de Studii ale Religiei, Universitatea din Sydney, Australia. 
662) ${ }^{1}$. Toți trei au discutat convingerea sa potrivit căreia cuplurile căsătorite pot ajunge la sfințenie, aici și acum - sacramental, moral și spiritual - stare pe care o vor experia deplin doar eshatologic ${ }^{2}$. Mai multe sunt de spus. Eu însumi am scris trei studii, dintre care primul se ocupă integral cu problematici relevante, celelalte două atingând aceste chestiuni doar parțial. Primul este un articol publicat în 2013, în care vorbesc despre tema desăvârșirii în virtute ca mod de viață mai presus de gen, precum și despre reticența Sfântului Maxim de a gândi perfecțiunea ca asexualitate ${ }^{3}$. Al doilea este un capitol publicat în 2014, unde mă refer la chestiunea genului, a căsătoriei și a sfințeniei în context hermeneutic, dar ca exemplificare a unei teme de natură mai cuprinzătoare ${ }^{4}$. Cel de-al treilea studiu discută contextul literar şi ideatic imediat al unuia dintre pasajele relevante aici, Ambigua $41^{5}$.

În cele ce urmează voi continua cercetările mele anterioare prin discutarea faptului că, în Ambigua sau Cartea Dificultăților ${ }^{6}$,

1 Acest articol reprezintă versiunea în limba română, revizuită și adăugită, a capitolului meu „Gender, Marriage, and Holiness in Amb.Io. 10 and 41”, publicat în Men and Women in the Early Christian Centuries, ed. Wendy Mayer și Ian J. Elmer, Early Christian Studies 18, Strathfield, NSW, St. Paul's Publications, 2014, p. 351-371. Mulțumesc editorilor volumului pentru permisiunea de a refolosi acel studiu în forma de față.

2 Adam G. CoOper, The Body in St Maximus the Confessor: Holy Flesh, Wholly Deified, Oxford Early Christian Studies, Oxford, Oxford University Press, 2005, p. 213, 218-227. Hans Urs von BALTHASAR, Cosmic Liturgy: The Universe According to Maximus the Confessor, trad. Brian E. Daley, San Francisco, CA, Ignatius Press, 2003, p. 196-205. Lars Thunberg, Microcosm and Mediator: The Theological Anthropology of Maximus the Confessor, Chicago and La Salle, IL, Open Court, 1995, p. 157-159, 376-377.

3 Doru Costache, „Living above Gender: Insights from Saint Maximus the Confessor”, în Journal of Early Christian Studies 21:2 (2013), p. 261-290.

4 IDEM, „The Transdisciplinary Carats of Patristic Byzantine Tradition”, în Transdisciplinary Education, Philosophy, \& Education, ed. Basarab Nicolescu și Atila Ertas, Lubbock, TX, The Academy of Transdisciplinary Learning \& Advanced Studies, 2014, p. 149-165.

5 IDEM, „Mapping Reality within the Experience of Holiness", în The Oxford Handbook of Maximus the Confessor, ed. Pauline Allen și Bronwen Neil, Oxford, Oxford University Press, 2015, p. 378-396.

6 Textul folosit aici este cel al recentei ediții critice. Vezi Maximos the Confessor: On Difficulties in the Church Fathers: The Ambigua, două volume, ed. Nicholas Constas, Dumbarton Oaks Medieval Library, Cambridge, MA and 
Sfântul Maxim Mărturisitorul despre gen, căsătorie și sfințenie (Ambigua 10 și 41)

Sfântul Maxim descrie căsătoria ca viețuire sfântă. Pasajele discutate aici $^{7}$ creionează o traiectorie existențială care începe cu eșecul unui cuplu de a realiza sfințenia (Ambigua 10.28), continuă cu afirmarea căsătoriei ca formă de atingere a sfințeniei echivalentă căii monastice (Ambigua 10.31a.5), încheind prin afirmarea cuplurilor sfinte ca întrupând standarde monahale (Ambigua 41). Aceasta este și ordinea în care voi discuta respectivele pasaje. În analiza de mai jos, mă voi referi mai ales la textele prime, dar în conversație cu cercetări recente. Ultima secțiune a studiului va introduce conceptul lui Evdokimov - „monahism interiorizat” - ca instrument metodologic menit să unifice mesajul textelor în discuție, din Ambigua 10 și 41. Scopul acestui studiu este de a pune în evidență semnificația reprezentării maximiene a genului și a căsătoriei în contextul proiectului său de cartografiere a experienței sfințeniei. Sper ca rezultatele studiului de față să aducă la lumină o verigă lipsă în studiul contemporan al spiritualității și culturii bizantine privind genul și căsătoria. Într-adevăr, cercetarea actuală fie ignoră contribuțiile sfântului Maxim $^{8}$, fie necesită investigații mai serioase decât până acum .

\section{Explorând Ambigua 10}

Constituind un adevărat tratat despre sfințenie, Ambigua 10 se referă de două ori la familie în sensul de cale a sfințeniei. Înainte

London, Harvard University Press, 2014. Pentru că ediția din Patrologia Graeca (PG) vol. 91 este mai cunoscută, voi da și referințe la aceasta.

$7 \mathrm{Nu}$ am inclus aici și discutarea secțiunii relevante din Ambigua 67 (On Difficulties, vol. 2:296-298; PG 91, 1401AB). Pentru o analiză a acestui pasaj, vezi D. CostaCHE, „Living above Gender”, p. 268-272, p. 274-277.

8 Vezi Approaches to the Byzantine Family, ed. Leslie Brubaker și Shaun

Tougher, Birmingham Byzantine and Ottoman Studies 14, Farnham, Ashgate, 2013; Alexander Kazhdan et al., A History of Byzantine Literature (650-850), Athens, National Hellenic Research Foundation, 1999; Questions of Gender in Byzantine Society, ed. Bronwen Neil and Lynda Garland, Farnham, Ashgate, 2013).

9 Vezi Bronwen NeIL, „An introduction to questions of gender in Byzantium”, in

Neil and Garland, Questions of Gender, p. 1-10, mai ales 3-7. 
de a discuta pasajele relevante, spre a înțelege mai bine contextul discuției trebuie să aruncăm o rapidă privire asupra conținutului acestui capitol al scrierii. Ambigua 10 este cel mai lung capitol al cărții ${ }^{10}$, tratând diverse aspecte și ilustrații scripturale ale experienței sfințeniei, astfel încât rezumarea sa se dovedește a fi o întreprindere hazardată ${ }^{11}$. Pe scurt, uriaşul text discută semnificaţia norului și a vălului menționate în pasajul din sfântul Grigorie Teologul care-i servește ca pretext ${ }^{12}$; activitățile sufletului și aspirația sa de a se uni cu Dumnezeu ${ }^{13}$; dimensiunea tipologică a faptelor lui Avraam ${ }^{14}$, Melchisedec ${ }^{15}$, Moise ${ }^{16}$, Iosua ${ }^{17}$, Samuel ${ }^{18}$, Ilie $^{19}$ și Elisei ${ }^{20}$; și, în sfârșit, impactul schimbării Domnului la față ${ }^{21}$. Transfigurarea lui Hristos ocupă un spațiu important în capitol, fiind lentila hermeneutică a întregului discurs. Toate aceste idei şi exemple gravitează în jurul temei centrale, anume, experiențele și percepțiile sfinților ${ }^{22}$. Sfinții, adoptând virtutea, abandonează viața pătimașă reprezentată de Adam și de Eva ${ }^{23}$, progresând către o înțelegere deopotrivă mistică și unificată a

${ }^{10}$ On Difficulties, vol. 1:150-342. Cf. PG 91,1105C-1205C.

11 Vezi asemenea încercări la Andrew Louth, Maximus the Confessor, The Early Church Fathers, London and New York, Routledge, 1996, p. 91-93; Polycarp SHERwoOd, The Earlier Ambigua of Saint Maximus the Confessor and His Refutation of Origenism, Studia Anselmiana 36, Rome, Herder, 1955, p. 30-40. Niciunul din acești autori nu a sesizat că scopul capitolului este cartografierea experienței sfințeniei.

12 On Difficulties, vol. 1:158-160. Cf. PG 91,1112A-D.

13 On Difficulties, vol. 1:161-170. Cf. PG 91,1112D-1116D.

${ }^{14}$ On Difficulties, vol. 1:228-230. Cf. PG 91,1145C-1148A, 1200AB.

${ }^{15}$ On Difficulties, vol. 1:212-226. Cf. PG 91,1137C-1145B.

16 On Difficulties, vol. 1:168-174, 228-236, 330-334. Cf. PG 91,1116D-1117D, 1148A-1149C, 1200C-1201B.

17 On Difficulties, vol. 1:174-178. Cf. PG 91,1117D-1120D.

18 On Difficulties, vol. 1:186. Cf. PG 91,1124D-1125A.

${ }^{19}$ On Difficulties, vol. 1:180-184. Cf. PG 91,1121C-1124B.

${ }^{20}$ On Difficulties, vol. 1:184, 188. Cf. PG 91,1124C, 1125BC.

21 On Difficulties, vol. 1:190-194, 252-276. Cf. PG 91,1125D-1128D, 1160B$1169 \mathrm{~B}$.

22 On Difficulties, vol. 1:194-212, 234-246, 250-254, 278-328. Cf. PG 91,1129A1137C, 1149C-1156B, 1157B-1160B, 1172A-1197D.

${ }^{23}$ On Difficulties, vol. 1:246-248. Cf. PG 91,1156C-1157A. 
Sfântul Maxim Mărturisitorul despre gen, căsătorie și sfințenie (Ambigua 10 și 41)

realității - scripturală și cosmică, vizibilă și invizibilă, istorică și eshatologică - ca dumnezeiește creată și providențial condusă către îndumnezeire în comuniune cu Dumnezeu.

Din toată această bogăție de idei, în cele ce urmează mă voi referi la cele două pasaje anunțate, care tratează genul și viaţa de familie. Primul text discută despre Adam și Eva ca un cuplu care a eșuat în efortul de realizare a sfințeniei, în vreme ce al doilea se concentrează asupra validității căsătoriei, a cărei ilustrare este Moise, ca formă de realizare a sfințeniei. Timpul a venit să discutăm primul pasaj.

\section{Soția lui Adam}

În discuția despre cădere, mai devreme, în Ambigua 7, Sfântul Maxim a numit-o pe Eva desfrânată ${ }^{24}$. Se pare că această jignire, la care m-am referit în altă parte ${ }^{25}$, făcea parte din arsenalul său retoric, prin care încerca să atragă atenţia asupra gravității alegerii lui Adam de a asculta de soția sa mai mult decât de Dumnezeu. Mărturisitorul s-a întors la naraţiunea despre paradis în Ambigua 10.28, punând mai bine în evidență dramaticele schimbări suferite de sfinți care, după ce au văzut slava lui Dumnezeu, se întorc la viața pătimașă, la dependența față de cele pământești ${ }^{26}$. Mai precis, continuând tema pasajului din Ambigua $7,{ }^{27}$ secțiunea relevantă din Ambigua $10^{28}$ discută două posibilități la îndemâna lui Adam. Astfel, protopărintele

${ }^{24}$ On Difficulties, vol. 1:120. Cf. PG 91,1092D.

25 Vezi Doru Costache, „Living above Gender”, p. 264-267.

${ }^{26}$ On Difficulties, vol. 1:246. Cf. PG 91,1156C. Vezi Jean-Claude LARCHET, La divinisation de l'homme selon saint Maxime le Confesseur, Paris, Cerf, 1996, p. 178-186, p. 187-201. Tema căderii sfinților a fost îndelung exploatată în literatura patristică şi monastică anterioară sfântului Maxim. Vezi Doru Costache, „Adam's Holiness in the Alexandrine and Athonite Traditions”, în Alexandrian Legacy: A Critical Appraisal, ed. Doru Costache, Philip Kariatlis and Mario Baghos, Newcastle upon Tyne, Cambridge Scholars Publishing, 2015, p. 322-368.

${ }^{27}$ On Difficulties, vol. 1:120. Cf. PG 91,1092CD.

${ }^{28}$ On Difficulties, vol. 1:246-248. Cf. PG 91,1156C-1157A. 
putea fie să mențină comuniunea cu Dumnezeu şi să fie luminat cu adevărul de sus, ori să aleagă o existență orientată spre cele pământești și să devină ignorant în toate, în primul rând în cele dumnezeiești ${ }^{29}$. Prima posibilitate era semnalată de mâncarea din pomul vieții și ar fi dus la nemurire ${ }^{30}$. Cea de a doua, semnificată de mâncarea din pomul interzis, însemna permanentizarea morții pe tot parcursul acestei vieți ${ }^{31}$.

Asemănător capitolului al șaptelea, Ambigua 10.28 îl arată

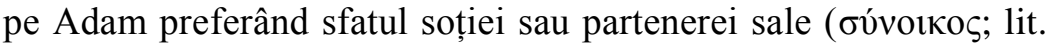
cineva care locuiește în aceeași casă) ascultării de Dumnezeu ${ }^{32}$. Astfel a făcut el însuși o alegere greșită, experimentând consecințele ce au decurs din această alegere. Există o diferență însă între modul în care Sfântul Maxim a tratat aceste chestiuni aici, faţă de Ambigua 7: invectiva contra Evei nu mai apare de această dată. Politețea arătată aici pare să fie cerută de tema capitolul al zecelea - căile sfințeniei - o temă care a impus adoptarea unei înțelegeri diferite a narațiunii scripturale. Mai precis, în contextul capitolului de interes, referirile negative la viața de familie trebuia să fie evitate. $\mathrm{Nu}$ mai era nevoie de aplicarea unor mijloace retorice de atragere a atenţiei asupra riscurilor neascultării. Este foarte posibil ca în acest context Mărturisitorul să se fi gândit și la exemple concrete de cupluri sfinte, pe care le respecta.

Ceea ce contează, aici, este semnificația cuvântului бúvoıkos, soție sau parteneră, care traduce întregul eveniment într-unul de natură maritală. În acest context, aşadar, nu este nicio îndoială că în paradis Adam și Eva erau căsătoriți și că locuiau în

${ }^{29}$ On Difficulties, vol. 1:256. Cf. PG 91,1156C.

${ }^{30}$ On Difficulties, vol. 1:248. Cf. PG 91,1156D-1157A.

${ }^{31}$ On Difficulties, vol. 1:248. Cf. PG 91,1156D, 1157A.

32 On Difficulties, vol. 1:248. Cf. PG 91,1156D. Traducerea lui Louth, Maximus

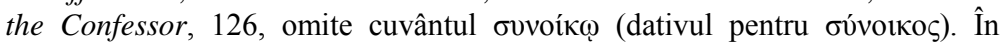
schimb, traducerile lui Dumitru Stăniloae, în Sfântul Maxim Mărturisitorul: Scrieri, partea întâi, București, Edit. Institutului Biblic şi de Misiune al Bisericii Ortodoxe Române, 1983, p. 155 și Emmanuel Ponsoye, în Saint Maxime le Confesseur: Ambigua, Paris și Suresnes, L' Ancre, 1994, p. 189, nu-1 ocolesc. 
Sfântul Maxim Mărturisitorul despre gen, căsătorie și sfințenie (Ambigua 10 și 41)

aceeaşi casă, nefiind numai doi oameni pe care Dumnezeu i-a creat. $\mathrm{Cu}$ toate că nu a acordat atenție termenului бúvoıкos, Larchet nota cu dreptate că Sfântul Maxim a înțeles istorisirea despre strămoșii paradisiaci ca o pildă despre condiția umană în general ${ }^{33}$. Dar, din punctul meu de vedere, rescrierea maximiană a narațiunii din Facerea în cheie conjugală a fost condiționată de mai mult decât de ideea că fiecare parte a Scripturii vorbește despre experiența poporului lui Dumnezeu ca întreg; factorul la care mă gândesc, o dată mai mult, este evidența unor familii sfinte pe care Mărturisitorul le-a întâlnit sau despre care i s-a povestit. Voi reveni la această chestiune, care mi se pare crucială din punct de vedere hermeneutic. În acest punct este de ajuns să spun doar atât, că interpretarea Scripturii în lumina unor experiențe contemporane era profund ancorată în tradiție ${ }^{34}$.

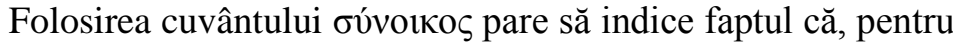
Sfântul Maxim, eșecul protopărinților a constat în alegerea unei vieți fără înțelepciune. Narațiunea scripturală privește familia ca loc al unor teste de natură spirituală și, în acest caz, ca încercare eșuată de a trăi pe un plan duhovnicesc superior. Dată fiind sărăcia detaliilor furnizate de Ambigua 10.28, mai mult decât atât nu se poate spune despre această situație. Dar, fie și așa, includerea Evei ca soție și sfătuitoare a soțului său solicită rediscutarea opiniei de astăzi potrivit căreia cultura bizantină a pictat un chip schematic al femeii redus la tipologia desfrânatei pocăită, a soției abuzată de soț și a fecioarei ascetă $\breve{s}^{35}$. Aceste nuanțe solicită de asemenea o

${ }^{33}$ LARCHET, La divinisation de l'homme, p. 182.

34 Vezi John BeHR, The Formation of Christian Theology, Crestwood, NY, St. Vladimir's Seminary Press, 2001, 1:17-70, unde se discută chestiunea interpretării Vechiului Testament de către apostoli în lumina experienței lor cu Iisus Hristos. Vezi şi Costache, „Adam's Holiness”, p. 326-337, pentru un principiu asemănător în lumea monahală și în tradiția patristică: asceții contemporani scriitorilor deveneau cheia interpretativă pentru descifrarea Scripturilor.

35 Astfel, Eamon H. R. KELly, „From 'fallen woman' to Theotokos: Music, women's voices and Byzantine narratives of gender identity”, în Byzantine Narrative: Papers in Honour of Roger Scott, ed. John Burke et al., Byzantina Australiensia 16, Melbourne, Australian Association for Byzantine Studies, 
schimbare a înțelegerii că, pentru Sfântul Maxim şi alți sfinţi părinți, genul și căsătoria sunt realități care țin exclusiv de experiența căzută, păcătoasă a omenirii ${ }^{36}$.

Un alt aspect interesant apare în ultima propoziţie a pasajului în discuție; am atins deja acest aspect prin referirea la interpretarea lui Larchet. Fără a o spune direct, Sfântul Maxim arată aici că eventimentele vieții protopărinților - inclusiv caracterul muritor - exemplifică și condiţionează experiența generală a umanității. În cuvintele sale, ,moartea trăiește pe tot parcursul acestui spațiu temporal, noi fiind mâncarea pe care o mănâncă" ${ }^{37}$. În economia pasajului și privită din perspectiva

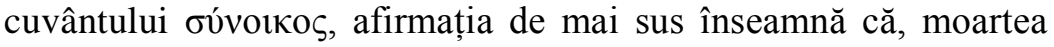
tuturor oamenilor fiind identică morții cuplului paradisiac, experiența lui Adam și a Evei este tipică pentru orice alte cupluri în istorie. Se poate spune că, în timp ce se referea la strămoșii paradisiaci ca familie testată spiritual și care a eșuat, Sfântul Maxim făcea aluzie și la reversul medaliei. Mai precis, în rescrierea sa evenimentele paradisiace denotau, exemplar, calea sfințeniei în general. Așa cum Mărturisitorul interpreta narațiunea scripturală în lumina vieții unor cupluri sfinte pe care le cunoștea, sau de care auzise, tot astfel privea experiența acestor cupluri prin lentila clarificatoare a narațiunii. Mai departe, naraţiunea despre strămoși devenea cheia pentru descifrarea circumstanţelor personale ale cititorilor ${ }^{38}$. Aceste concluzii corespund perfect

2006, p. 164-181, mai ales 167-168. Vezi și Stavroula Constantinou, „Virginity in danger: Holiness and sexuality in the Life of Mary of Antioch", în

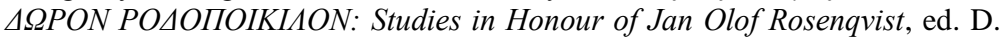
Searby, E. B. Witakowska și J. Heldt, Studia Byzantina Upsaliensia 12, Uppsala, Acta Universitatis Upsaliensis, 2012, p. 123-132, mai ales 126. În antichitatea târzie, portretul femeii creștine nu era atât de simplist. Vezi Wendy MAYER, „Constantinopolitan women in Chrysostom's circle”, în Vigiliae Christianae 53.3 (1999), p. 265-288.

${ }^{36}$ COOPER, The Body, 214-215; Damien CASEY, , The spiritual valency of gender in Byzantine society", in Neil and Garland, Questions of Gender, p. 167-181, mai ales 168 .

${ }^{37}$ Vezi Ambigua 10.28. On Difficulties, vol. 1:248. Cf. PG 91,1157A.

38 Doru Costache, „Living above gender”, p. 282-283. Această formă de interpretare era comună în Bizanț. Vezi Doru CosTACHE, „Înțelegeri Bizantine: 
Sfântul Maxim Mărturisitorul despre gen, căsătorie și sfințenie (Ambigua 10 și 41)

schemei din Ambigua 10, capitol al cărui scop, am văzut, este de a identifica reliefurile experienței sfințeniei. Dar a sosit momentul să-mi întorc privirea spre un alt pasaj din Ambigua 10, care vorbește despre căsătorie ca o cale de realizare a sfințeniei.

\section{Experiența conjugală}

Am menționat deja că în Ambigua 10 schimbarea la faţă a Domnului ocupă un loc proeminent. Aici, Sfântul Maxim a contemplat evenimentul taboric în două împrejurări, mai întâi concentrându-se asupra firii umane și a hainelor Mântuitorului înțelese ca semnificând Scriptura și creația ${ }^{39}$-, iar apoi asupra celor doi profeți prezenți pe Tabor, simboluri ale multor semnificații ${ }^{40}$. În cele ce urmează mă voi referi la o porțiune din cel de-al doilea context.

Pasajul relevant se află în Ambigua $10.31 \mathrm{a} .5^{41}$. Se referă la Moise și Ilie ca simboluri ale căsătoriei și ale necăsătoriei (monahismului), respectiv. Textul afirmă că prin prezența lor lângă Hristos cei doi profeți semnifică „tainele căsătoriei și necăsătoriei”

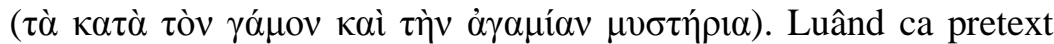
faptul că Moise era căsătorit în timp ce Ilie era celibatar, Sfântul Maxim sugera că atât căsătoria, cât și necăsătoria sunt căi spirituale eficiente. Mai precis, Moise nu a fost ,împiedicat de căsătorie să devină un însetat după slava dumnezeiască”, în timp ce Ilie ,a

Cartea Facerii, Teologie și Spiritualitate în Canonul cel Mare al sfântului Andrei Cretanul", în Imnografia liturgică bizantină: Perspective critice, ed. Alexandru Ioniță, Studia Oecumenica 13, Cluj-Napoca, Presa Universitară Clujeană, 2019, p. 179-216; IDEM, „Andrew of Crete's Great Canon, Byzantine Hermeneutics, and Genesis 1-3", în Hymns, Homilies and Hermeneutics in Byzantium, ed. Andrew Mellas and Sarah Gador-Whyte, Byzantina Australiensia 25, Leuven and Boston, Brill, 2020, p. 67-85; IDEM, „Byzantine insights into Genesis 1-3: St. Andrew of Crete's Great Canon”, în Phronema 24 (2009), p. 35-50.

${ }^{39}$ On Difficulties, vol. 1:190-212. Cf. PG 91,1125D-1137C.

${ }^{40}$ On Difficulties, vol. 1:254-274. Cf. PG 91,1160C-1169B.

${ }^{41}$ On Difficulties, vol. 1:260. Cf. PG 91,1161D. Pentru note asupra acestui pasaj, vezi D. Costache, „Living above gender”, p. 287-288. 
rămas cu totul curat de orice relație maritală". Totuși, chiar dacă circumstanțele lor sociale difereau, cei doi profeți au ajuns la aceeași desăvârșire în unire cu Dumnezeu. Nu ne poate surprinde așadar concluzia Sfântului Maxim că, în această lumină, ambele căi, căsătoria și necăsătoria, sunt căi valide spre desăvârșire. Amândouă îi conduc pe cei care trăiesc ,rațional” ( $\lambda$ ó $\left.\omega_{\uparrow}\right)$, potrivit legilor (vó $\mu$ ov $\varsigma)$ dumnezeiește stabilite $(\theta \varepsilon \imath \omega \delta \tilde{\omega} \varsigma)$, la situaţia de a fi

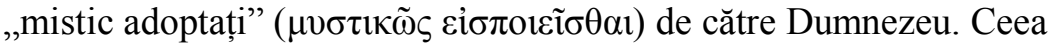
ce contează este concluzia că viața de familie constituie o cale de realizare a sfințeniei. Un număr de nuanțe pot fi discernute în această concluzie.

Chiar dacă pasajul nu menționează explicit dimensiunea morală sau ascetică, aceasta nu poate fi ignorată nici aici, nici în alte părți, Sfântul Maxim văzând-o ca o condiție necesară pentru călătoria duhovniceasc $\breve{a}^{42}$. In textul de interes, dimensiunea etică apare în referirea la ascultarea de poruncile dumnezeiești în mod rațional, care corespunde convingerii maximiene că virtutea înseamnă a trăi rațional ${ }^{43}$. Așadar, modul rațional de înfăptuire a desăvârşirii este virtutea ${ }^{44}$, obiectul prin excelență al eticii clasice. În această lumină, când sunt trăite virtuos, potrivit înţelepciunii divine exprimate prin porunci, cele două stări căsătoria și celibatul -conduc la Hristos și la adopțiunea mistică. Iar cum virtutea este numitorul comun al tuturor creștinilor ${ }^{45}$, faptul că textul nostru o ia ca punct de plecare pentru realizarea sfințeniei denotă posibilitatea ca toți oamenii să poată merge pe calea vieții spirituale, indiferent de sexul și de circumstanțele lor sociale. Pasajul considerat aici indică relevanță gândirii

42 Vezi Polycarp SHerwood, „Introduction” to St. Maximus the Confessor: The Ascetic Life and The Four centuries on Charity, Westminster, MD și London, The Newman Press și Longmans, Green and Co., 1955, p. 3-102, mai ales 8386; Louth, Maximus the Confessor, p. 35-36.

${ }^{43}$ Vezi Ambigua 7.22. On Difficulties, vol. 1:104. Cf. PG 91,1084B.

44 Pentru virtute ca mod rațional de viață, vezi LARCHET, La divinisation de l'homme, p. 466-476; D. CosTACHE, „Living above gender”, 274-275.

45 Vezi A. Louth, Maximus the Confessor, 34-35; D. Costache, „Living above gender”, p. 275. Despre puterea unificatoare a virtuții, vezi Ambigua 67 (On Difficulties, vol. 2:290; PG 91, 1397C). 
Sfântul Maxim Mărturisitorul despre gen, căsătorie și sfințenie (Ambigua 10 și 41)

Mărturisitorului pentru cercuri mult mai largi decât primii destinatari ai scrierii - bărbați și monahi - cărora le descoperă că experiența căsătoriei este echivalentă ca formă de realizare a sfințeniei oricărei alteia.

Un aspect care merită atenție, așadar, este proclamarea căsătoriei ca viețuire sfântă. Aici, sfințenia nu pare să necesite suprimarea condiției sexuale a cuplului ${ }^{46}$. Corespunzând sfintelor familii care au făcut obiectul literaturii bizantine - vezi hagiografia Sfântului Alexie Omul-lui-Dumnezeu, din secolul al optulea ${ }^{47}$, și cea a sfântului Filaret din Amnia, din secolul al nouălea ${ }^{48}$ - Moise, reprezentând căsătoria, a avut copii cu soția sa fără ca aceasta să-l împiedice de la sfințenie. Pasajul considerat aici introduce această nuanță prin contrapunctul modului în care cei doi profeți au ajuns la desăvârșire. Ilie a devenit perfect prin evitarea unirii maritale, iar Moise a atins același nivel al sfințeniei chiar dacă s-a bucurat de căsătorie în toate aspectele acesteia, inclusiv fizice. Ceea ce sfințește căsătoria nu este renunțarea la bucuria și plăcerea trăite de un cuplu iubitor, ci faptul de a da prioritate virtuții și căutărilor duhovnicești. În lectura Sfântului Maxim, Moise a ilustrat acest înțeles prin faptul de a fi devenit ,iubitor al slavei dumnezeiești”

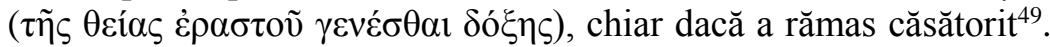

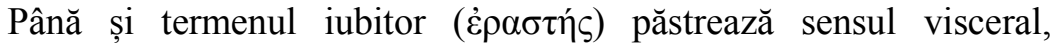
întrupat al iubirii - eros - spre deosebire de celelalte forme ale dragostei, ca raportare elevată la obiect $(\dot{\alpha} \gamma \alpha \pi \alpha ́ \omega)$ și în sensul stabilirii unei prietenii $(\varphi \imath \lambda \varepsilon ́ \omega)$. Mărturisitorul pare să spună că Moise Îl iubea pe Dumnezeu la fel de arzător cum își iubea soția, posibil făcând aluzie la imagistica erotică a Cântării Cântărilor și a tradiției patristice de interpretare a acestei cărți.

46 Pentru mai multe despre conceptul maximian al căsătoriei, vezi COOPER, The Body in St Maximus the Confessor, 208-218; D. Costache, „Living above Gender", p. 268-77, 281-86.

${ }^{47}$ Vezi Stavroula Constantinou, „Family in the Byzantine Greek Legend of Saint Alexios, the Man of God", în Brubaker and Tougher, Approaches to the Byzantine Family, p. 273-284, mai ales 274, 277.

${ }^{48}$ Vezi KAZHDAN et al., A History of Byzantine Literature, 288-290.

${ }^{49}$ On Difficulties, vol. 1:260. Cf. PG 91,1161D. 
Fie și indirect, aceste nuanțe proiectează o lumină clarificatoare asupra implicațiilor cuvântului oúvoıkos întâlnit mai devreme, în Ambigua 10.28. Cu sau fără a avea copii, Adam și Eva aveau chemarea de a devini un cuplu sfânt, dar au eșuat. Indiferent de acest eșec şi de cum a decurs călătoria altor sfinte cupluri, important este mesajul Sfântului Maxim potrivit căruia căsătoria este o cale spre sfințenie. Prin comunicarea acestui mesaj, el s-a dovedit a fi un precursor al literaturii hagiografice bizantine, care, în secolul al nouălea, a arătat un sporit interes în explorarea sfințeniei vieții de familie ${ }^{50}$. Contribuția sa încă așteaptă recunoaștere.

Totuși, evaluare pozitivă a căsătoriei de către sfânt pare să fie relativizată în economia interpretării evenimentului taboric. Astfel, în Ambigua $10.31 \mathrm{a}^{51}$ cele două căi, căsătoria și celibatul, nu par echivalente sau la fel de eficiente. Ilie și Moise nu mai apar aici pe picior de egalitate. Pasajul conține o listă de opt aspecte asociate cu experiența lui $\mathrm{Ilie}^{52}$, aspecte prețuite atât de Sfântul Maxim, cât și de mediul monastic din care făcea parte, și alte opt aspecte reprezentate de Moise $^{53}$. Seria reprezentată de Ilie pare să fie superioară celei asociată lui Moise. Potrivit lui Cooper, dând prioritate lui Ilie și seriei de înţelesuri pe care acesta le reprezintă, Mărturisitorul și-a exprimat preferința pentru celibat și pentru viața monastică $\breve{s}^{54}$. Totuși, în textul nostru această preferință apare numai în legătură cu ultimul din cele opt elemente comparate - în sensul superiorității aspectului noetic,

50 Vezi Kelly, „From ‘fallen woman' to Theotokos”, p. 171-172.

51 On Difficulties, vol. 1:254-264. Cf. PG 91, 1160C-1165A.

52 Acestea sunt: spiritul profetic, bunătatea, educația, contemplația, celibatul, moartea, natura și realităţile noetice. On Difficulties, vol. 1:256-264. Cf. PG 91,1161A-1165A.

53 Acestea sunt: principiul ori spiritul legii, înțelepciunea, cunoaşterea, asceza, căsătoria, viața, timpul și realitățile materiale. On Difficulties, vol. 1:256-264. Cf. PG 91,1161A-1165A.

54 Adam G. COOPER, „Saint Maximus on the mystery of marriage and the body: A reconsideration", în Knowing the Purpose of Creation through the Resurrection, ed. Bishop Maxim Vasiljević, Contemporary Christian Thought Series 20, Alhambra, CA, Sebastian Press, 2013, p. 195-221, mai ales 204-207. 
Sfântul Maxim Mărturisitorul despre gen, căsătorie și sfințenie (Ambigua 10 și 41)

ori spiritual, al realității față de cel material ${ }^{55}$. Acestea fiind zise, Sfântul Maxim nu a arătat dispreț pentru cele opt aspecte asociate cu Moise și, de fapt, le-a prezentat într-o lumină favoribilă, evidentă, am văzut mai sus, în afirmația că la Hristos ajung și cei căsătoriți, nu doar cei necăsătoriți. Acest înțeles provine fără îndoială dintr-o percepție holistică, incarnațional ${ }^{56}$, care nu reduce complexitatea lucrurilor la vreuna din cele două serii. Această chestiune merită mai multă atenție.

Am arătat mai sus că ultima pereche tratată în acest pasaj referindu-se la realităţile noetice semnificate de Ilie și la cele senzoriale asociate lui Moise - conține un dezechilibru, în sensul că Sfântul Maxim preferă aspectul noetic al lucrurilor. $\mathrm{Cu}$ toate acestea, celelalte șapte perechi - spiritul legii și spiritul profetic, înțelepciunea și bunătatea, cunoașterea și educația, asceza și contemplația etc. - indică spre Hristos și/sau Dumnezeu în egală măsură, corespunzând celor doi profeți care au stat lângă Domnul pe Tabor. Am discutat conținutul celor două serii și relațiile dintre ele în altă parte ${ }^{57}$. Acolo am arătat că cele opt perechi țintesc spre sinteze mai înalte și că cea de a cincea pereche, privind căsătoria și celibatul, sugerează atingerea sfințeniei în manieră directă şi indirectă, nu incapacitatea vreuneia pentru sfințenie.

Concluzia la care am ajuns în acel studiu află confirmare într-o altă scriere maximiană din aceeaşi perioadă nord-africană de la începutul anilor 630. Este vorba despre Mistagogia, o carte al cărei al cincelea capitol prezintă o listă de cinci perechi care amintesc de Ambigua 10.31a. Cele cinci perechi sunt următoarele: mintea și rațiunea, înțelepciunea și prudența, contemplația și

55 On Difficulties, vol. 1:262-264. Cf. PG 91,1164D-1165A.

56 Despre gândirea incarnaţională a Sfântului Maxim, vezi Ian A. McFARLAND, „Fleshing out Christ: Maximus the Confessor's Christology in Anthropological Perspective", în St. Vladimir's Theological Quarterly 49.4 (2005), p. 417-436; Fedor STANJEVSKIY, „Une anthropologie à la base d'une pensée religieuse: L'unité de l'homme dans la théologie de Maxime le Confesseur', în Forum Philosophicum 12 (2007), p. 409-428.

${ }^{57}$ Vezi D. Costache, „Transdisciplinary Carats”, 155-156. 
asceza, cunoaşterea şi virtutea, cunoașterea neîndoielnică și credința. Trei pasaje din Mistagogia $5^{58}$ afirmă complementaritatea elementelor care compun cele cinci perechi, faptul că niciunul din aceste elemente nu este inferior corespondentului său, şi că cele cinci perechi află unitate prin referire la Dumnezeu. Alte cinci perechi de elemente convergente - creatul și necreatul, noeticul și senzorialul, cerul și pământul, paradisul și lumea locuită, bărbatul şi femeia - sunt întâlnite în Ambigua $41^{59}$, pe care-l voi analiza mai jos. Şi în acest caz, diferențele dintre elementele enumerate nu implică evaluări calitative, în sensul că unul este superior celuilalt. Convergența pasajelor din Ambigua 41 și Mistagogia 5 clarifică sensul secțiunii de interes din Ambigua 10.31a. Date fiind cele de mai sus, în pofida preferinței sale pentru aspectele asociate lui Ilie - în special celibatul, sau viaţa monahală, corespunzând felului său de viață - este limpede că Sfântul Maxim privea căsătoria ca un perfect mediu pentru realizarea sfințeniei.

Pe această notă, analiza mea trece la pasaje semnificative din Ambigua 41, unde sunt discutate încercările trăite de cuplurile sfinte în drumul spre desăvârșire.

\section{Explorând Ambigua 41}

În cadrul complexei teorii sau narațiuni despre tot și toate din Ambigua $41^{60}$, prezentând natura eterogenă a realității prin

58 Mistagogia 5. Vezi Maximi Confessoris Mystagogia, una cum latina interpretatione Anastasii Bibliothecarii, ed. Christian Boudignon, Corpvs Christianorvm Series Graeca 69, Turnhout, Brepols Publishers, 2011, 21.31822.327; 22.337-23.346; 26.415-27.418.

${ }^{59}$ On Difficulties, vol. 2:102. Cf. PG 91, 1304D-1305A.

60 On Difficulties, vol. 2:102-120. Cf. PG 91,1304D-1316A. Interpretarea standard este cea a lui ThunBerg, Microcosm and Mediator, p. 373-427. Vezi și McFarland, „Fleshing out Christ”, p. 427-433; D. CostaChe, „Living above gender”, p. 278-281; IDEM, „Seeking out the Antecedents of the Maximian Theory of Everything: St. Gregory the Theologian's Oration 38", în Cappadocian Legacy: A Critical Appraisal, ed. Doru Costache and Philip Kariatlis, Sydney, St. Andrew's Orthodox Press, 2013, p. 225-241. 
Sfântul Maxim Mărturisitorul despre gen, căsătorie și sfințenie (Ambigua 10 și 41)

intermediul a cinci polarități și a cinci sinteze corespunzătoare, Sfântul Maxim a inclus importante referiri la gen, la sexualitate și la familie. Paragrafele relevante aici discută a cincea polaritate ori diviziune și prima sinteză ori unificare. Spre a înțelege semnificația acestor elaborări este necesar un rezumat al capitolului.

Discursul maximian în Ambigua 41 se desfășoară în cinci părți, anume, prologul și lista celor cinci diviziuni, de la realitatea în ansamblul său creat și necreat până la dualitatea de gen a ființei umane ${ }^{61}$; proiectul celor cinci unificări, în oglindă, începând de la omenire și încheind cu sinteza ultimă dintre creat și necreat ${ }^{62}$; căderea, disocierile produse de aceasta și antidotul lor, unificările înfăptuite de Hristos ${ }^{63}$; factorii care fac unificarea posibilă ${ }^{64}$; și interpretarea zicerii din Sfântul Grigorie Teologul despre „înnoirea firilor" în Hristos, care servește ca pretext pentru acest capitol ${ }^{65}$. Problematica genului face parte integrantă din acest discurs, apărând în posturi diferite în contextul schemei tripartită privind originile, căderea și mântuirea, dar și în funcție de contextul theanthropocosmic - Dumnezeu, umanitate, cosmos - armonizat prin cele cinci sinteze. Mărturisitorul nu concepe chestiunea genului în afara acestui context holistic, nici realitatea ca întreg fără prezența și activitatea umană. Generosul spațiu alocat aici pentru virtute și pentru realizarea sfințeniei cele mai înalte forme de activitate omenească - nu poate fi înțeles în afara acestui cadru cuprinzător. Am descris acest cadru, pe larg, în altă parte ${ }^{66}$. În cele ce urmează mă voi concentra asupra problematicilor genului și căsătoriei în contextul experienței sfințeniei.

${ }^{61}$ On Difficulties, vol. 2:102. Cf. PG 91,1304D-1305A.

${ }^{62}$ On Difficulties, vol. 2:102-108. Cf. PG 91,1305A-1308C.

${ }^{63}$ On Difficulties, vol. 2:108-114. Cf. PG 91,1308C-1312B.

${ }^{64}$ On Difficulties, vol. 2:114-118. Cf. PG 91,1312B-1313B.

${ }^{65}$ On Difficulties, vol. 2:120. Cf. PG 91,1313C-1316A.

${ }^{66}$ Vezi „Mapping Reality”, 379-390. 


\section{Gen, căsătorie și deplinătatea omenirii}

Cum am văzut deja, a cincea diviziune și prima unificare sunt de natură antropologică. Interesant este că în ambele cazuri, în loc de a obișnuitele discuții filosofice despre trup și suflet ${ }^{67}$, Mărturisitorul a ales să discute tema scripturală a relației dintre bărbat şi femeie, pe marginea narațiunilor din Facerea $1-3^{68}$. Omenirea divizată sexual trebuie să treacă testul celor cinci polarităti. Astfel, pentru că recapitulează în sine, ca microcosm, toate nivelurile ființei ${ }^{69}$, omenirea este chemată de către creator să conducă spre o sporită coerență diversele componente ale realitătiii. Îndeplinirea acestei sarcini este imposibilă fără a apropiere virtuoasă și rațională de lucruri, potrivit intenției divine. Testul imediat se referă la diviziunea sexuală a naturii umane, a cărei unificare condiționează celelalte patru sinteze ${ }^{70}$. Rezultatul procesului este unificarea realității prin realizarea unor forme superioare de organizare ${ }^{71}$. Acest rezultat nu constă însă în uniformizarea elementelor unificate; sintezele sunt complexe, păstrând neatinsă integritatea elementelor componente ${ }^{72}$. Așadar, este vorba despre unitate în diferență. Faptul devine evident de la prima sinteză, antropologică, Hristos unificând umanitatea prin

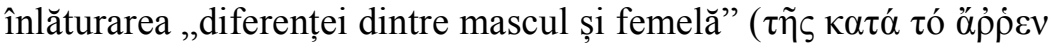

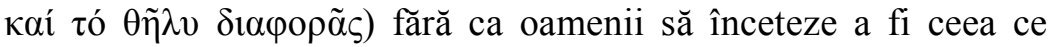
sunt, „ființe umane” sau oameni $(\dot{\alpha} v \theta \rho \omega ́ \pi \text { ov })^{73}$. Sinteza

${ }^{67}$ Pentru o opinie contrară, vezi STANJEVSKIY, „Anthropologie”, p. 415-419.

${ }^{68}$ On Difficulties, vol. 2:102. Cf. PG 91,1305AB.

${ }^{69}$ On Difficulties, vol. 2:102-104. Cf. PG 91,1305A-C.

70 Vezi Balthasar, Cosmic Liturgy, p. 199.

71 Vezi Costache, „Transdisciplinary Carats”, p. 99, 100.

72 Vezi Balthasar, Cosmic Liturgy, p. 56-80; Louth, Maximus the Confessor, p. 22-23, 49-51; CoOPER, The Body in St Maximus the Confessor, p. 9-13.

73 On Difficulties, vol. 2:112-114. Cf. PG 91,1309D-1312A. Termenii ä $\rho \dot{\rho} \varepsilon v$ (å $\rho \sigma \varepsilon v)$ şi $\theta \tilde{\eta} \lambda v$, preluați din Facerea 1, 27, sunt biologici, mascul şi femelă. Doar într-un singur loc folosește Sfântul Maxim aici termenii din

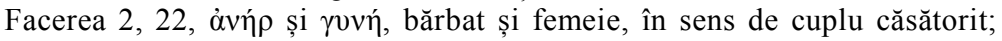
vezi Ambigua 41.9 (On Difficulties, vol. 2:114). 
Sfântul Maxim Mărturisitorul despre gen, căsătorie și sfințenie (Ambigua 10 și 41)

antropologică nu implică dizolvarea diferențelor genitale într-o natură umană amorfă $\breve{~}^{74}$.

Pe lângă aceste chestiuni de ordin principial, Sfântul Maxim a discutat sinteza antropologică în concret. Spre pildă, chiar dacă punctul său de plecare este planul divin privind unificarea creației, nu a ocolit problematica eșecului umanității. Omenirea a ales să trăiască într-o manieră contrară voinței lui Dumnezeu și virtuții. Această alegere a dus la subminarea existenței sale și, mai departe, a condus-o la ratarea șansei de a contribui la unificarea universului $^{75}$. Rezultatul acestei alegeri a fost dublu: omenirea a devenit incapabilă să scape de moarte, iar cosmosul a rămas într-o stare de risipire. Foarte relevant pentru acest studiu, și continuând o idee a lui Thunberg ${ }^{76}$, fărâmițarea cosmică este expresia la scară mare a eșecului oamenilor de a se raporta la problematica diferențierii de gen în mod dumnezeiesc. Sfântul Maxim a discutat această chestiune pe larg în alt $\operatorname{loc}^{77}$.

Mecanismul interior al dezastrului nu este dificil de identificat, avându-și sursa în răstălmăcirea de către umanitate a propriei naturi. Aceasta a condus-o la exploatarea pătimașă (vezi $\pi \alpha \rho \alpha \chi \rho \eta \sigma \alpha ́ \mu \varepsilon v o \varsigma, \pi \alpha \rho \alpha ́ \chi \rho \eta \sigma v^{78}$ a potențialului său natural, prin care genul, sexualitatea și plăcerea au devenit factori distructivi dincolo de sfera etică - existențial, ontologic şi cosmologic ${ }^{79}$. Transformarea diferențelor genitale în diviziuni era începutul unui proces derulat la scara macrocosmului. Așadar, omul fiind un microcosm în care se

${ }^{74}$ Pentru o altă perspectivă, vezi CASEY, ,The spiritual valency of gender”, p. 171.

75 On Difficulties, vol. 2:108. Cf. PG 91,1308C. Vezi ThunBERG, Microcosm and Mediator, p. 402-403.

76 ThunberG, Microcosm and Mediator, 377, a observat că, pentru Sfântul Maxim, plăcerea era mai ales de natură sexuală.

77 To Thalassius, prologue. Vezi Quaestiones ad Thalassium I, ed. C. Laga and C. Steel, Corpvs Christianorvm Series Graeca 7, Turnhout: Brepols, 1980, 7, 37.338-49.

78 On Difficulties, vol. 2:108, 111. Cf. PG 91,1308C, 1309A.

79 Vezi Paul M. BLowers, „Bodily Inequality, Material Chaos, and the Ethics of Equalization in Maximus the Confessor", în Studia Patristica 42 (2006), p. 51 56. 
regăsesc, recapitulate, toate părțile universului, orice acțiune umană reverberează cosmic. Antidotul pentru dezbinare era înfăptuirea sarcinii unificatoare a omenirii de către Logosul lui Dumnezeu întrupat. Hristos, „în calitate de om" ( $\dot{\omega} \varsigma$

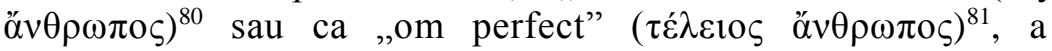
vindecat și a sfinţit umanitatea căzută și universul supus suferinței prin repunerea omenirii pe făgaşul activității unificatoare $^{82}$. A venit vremea să vedem mai îndeaproape ce spune capitolul despre chestiunile de imediat interes aici.

Ambigua 41 nu discută pe larg chestiunea genului ${ }^{83}$, limitându-se la menționarea directă a faptului că „umanitatea

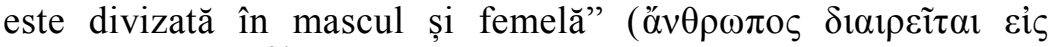

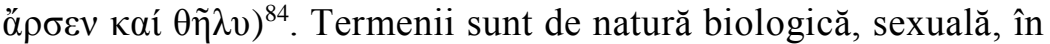
acest context denotând o dramatică polarizare a existenței omenești. Textul nu oferă nicio explicaţie privind sursa acestei diviziuni, după cum nici a primei diferențieri cosmice, între aspectele noetic și material al creației; cel puțin, nu lasă loc pentru interpretări de tip mitologic, precum posibilitatea unei diferențieri produsă de păcat, cum iau unii cercetători ${ }^{85}$ o aserțiune ipotetică a Mărturisitorului ${ }^{86}$. În lipsa unei clarificări în acest sens, de vreme ce capitolul cartografiază contururile realității, este foarte posibil ca Mărturisitorul să fi înțeles diviziunile ca ținând de natura lucrurilor. Mai precis, omenirea

${ }^{80}$ On Difficulties, vol. 2:112-114. Cf. PG 91,1309D.

81 On Difficulties, vol. 2:110. Cf. PG 91,1309A. Expresia este dezvoltată mai

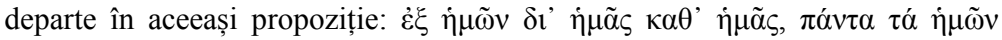

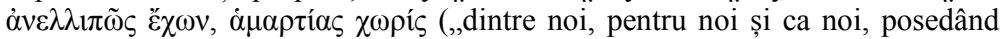
exact toate trăsătorile noastre, exceptând păcatul").

82 On Difficulties, vol. 2:108-110. Cf. PG 91,1308D.

${ }^{83}$ On Difficulties, vol. 2:102-104. Cf. PG 91,1305AB.

${ }^{84}$ On Difficulties, vol. 2:102. Cf. PG 91,1305A.

85 Vezi COOPER, The Body in St. Maximus the Confessor, p. 208-215; MCFARLAND, „Fleshing out Christ”, p. 427-428; Jean-Claude LARCHET, „Ancestral guilt according to St Maximus the Confessor: A bridge between Eastern and Western conceptions", în Sobornost 20.1 (1998), p. 26-48, mai ales 28, 38; Thunberg, Microcosm and Mediator, p. 373, 381.

${ }^{86}$ On Difficulties, vol. 2:110. Cf. PG 91,1309A. 
Sfântul Maxim Mărturisitorul despre gen, căsătorie și sfințenie (Ambigua 10 și 41)

este diferențiată sexual prin construcție ${ }^{87}$. Această înțelegere este confirmată în altă parte în Ambigua, unde sfântul vorbește despre diferența de gen ca ,îmbrățișată de Dumnezeu"88. Ca parte componentă a naturii umane, diviziunea sexuală nu este o tragedie ${ }^{89}$. Şi, de fapt, în economia capitolului analizat aici, Ambigua 41, a cincea diviziune a realității constituie o provocare existențială ca oricare alta, pe care omenirea, așadar, trebuie să o soluționeze prin unificare. Şi aici, ca și în textul din Ambigua 10.31, unificarea are loc prin viețuirea virtuoasă, care produce transformarea elementelor unificate, nu desființarea lor. Omenirea este chemată să trăiască virtuos, nu să renunţe la propria-i natură.

Privind mai îndeaproape proiectul sintezelor, Mărturisitorul le-a înțeles în sensul unei ascensiuni a omenirii spre Dumnezeu prin traversarea tuturor nivelurilor realității ${ }^{90}$, un proces menit să potențeze consistența acestor niveluri, inclusiv natura lor distinctă. Relevant pentru discuția de față este, desigur, începutul procesului unificator, anume depășirea aspectelor problematice ale diviziunii sexuale. Pasajul de mai jos reprezintă un ecou al discuției din Ambigua 10, în sensul că și aici, precum acolo, prima probă pe care umanitatea o are de înfruntat este viața conjugală. Dar iată ce spune textul: Scopul dumnezeiesc nu leagă în vreun fel

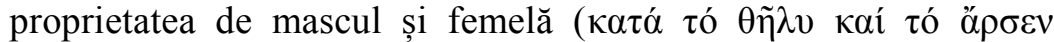
¡ $\delta$ ió $\eta \tau \alpha)$ de principiul antecedent ( $\pi \rho \circ \eta \gamma o v ́ \mu \varepsilon v o v ~ \lambda o ́ \gamma o v)$ al creării ființei umane. [Această proprietate] trebuie să fie complet curățată

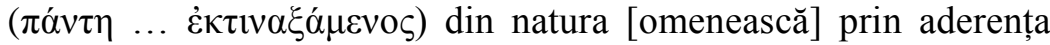

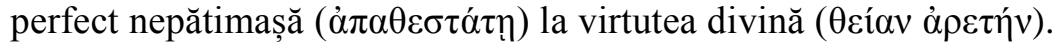
Așadar, în acord cu scopul dumnezeiesc, [ființa umană] trebuie să se arate și [într-adevăr] să devină doar om (őv $\theta \rho \omega \pi o v ~ \mu o ́ v o v)$,

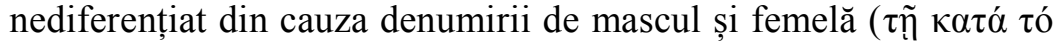

87 Pentru opinii contrare, vezi CostaCHE, „Living above Gender”, p. 272-274; MCFARLAND, „Fleshing out Christ”, p. 429.

88 Ambigua 67. On Difficulties, vol. 2:296-298. Cf. PG 91,1401AB. Vezi şi Costache, „Living above Gender”, p. 268-272.

${ }^{89}$ Pace vOn BALthaSAR, vezi Cosmic Liturgy, p. 294.

${ }^{90}$ On Difficulties, vol. 2:104. Cf. PG 91, 1305BC. 


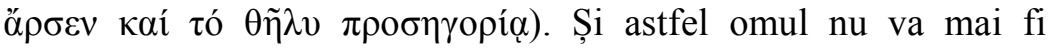
divizat - cum este acum, tăiat în bucăţi - în schimb ajungând să-și cunoască perfect propria rațiune de a fi, așa cum am zis deja, adică principiul antecedent potrivit căruia a venit la ființă $\breve{g 1}^{91}$.

Înălțarea către Dumnezeu se traduce aici, concret, ca manieră virtuoasă de viață sau, textual, ca aderență la ,virtutea divină”

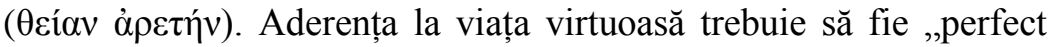

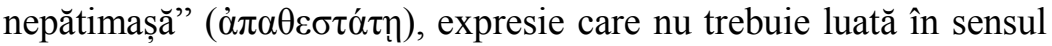
unei asceze menită să conducă la asexualitate. Numai în această lumină trebuie considerată afirmația despre „completa curățare”

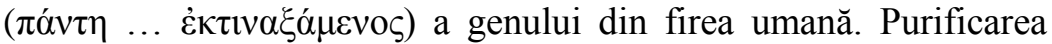
deplină, aici, semnifică realizarea virtuții, prin care umanitatea accede la un statut existențial unde trăsăturile genului devin estompate. Acest statut existenţial corespunde ,principiului

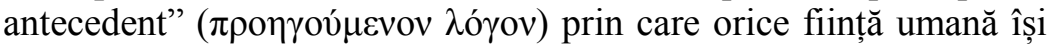
poate manifesta întregul potenţial natural, nedivizat, devenind ,doar

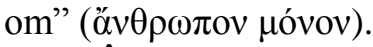

În această lumină, principiul antecedent constitutiv și viața virtuoasă converg întru înfăptuirea unei umanități interior unificată și deplin transformată. Virtutea, am aflat mai sus, nu are caracteristici specifice genului. Este un fel de viață care transcende genul. Similar, principiul constitutiv al omului constă în faptul de a fi creat după chipul lui Dumnezeu, cum spune Sfântul Maxim ceva mai târziu în Ambigua $41^{92}$, şi de aceea imposibil de articulat în sensul genului. Acestea fiind date, ,completa curățare” nu înseamnă desființarea trăsăturilor sexuale; în schimb, se referă la necesitatea de a elibera logosul ori principiul constitutiv al omului de opinia potrivit căreia acesta poate fi definit în termeni de fiziologie și reproducere. Eliberarea sau ,completa curățare” de opinii greșite înseamnă aflarea adevărului despre om ca ființă integrală, unificată și în care se regăsește întreg potențialul speciei - un adevăr ireductibil la gen și la orice alte atribute naturale care țin de sfera diviziunii. Pasajul de interes construiește acest contrast prin

${ }^{91}$ On Difficulties, vol. 2:104-106. Cf. PG 91, 1305CD.

92 On Difficulties, vol. 2:114. Cf. PG 91, 1312A. 
Sfântul Maxim Mărturisitorul despre gen, căsătorie și sfințenie (Ambigua 10 și 41)

evidențierea diferențelor dintre categoriile biologice „mascul și femelă" și categoria mai înaltă ori mai cuprinzătoare de om sau ființă umană (vezi őv $\theta \rho \omega \pi$ ov $\mu$ óvov $)^{93}$. Categoriile limitative trebuie interpretate în lumina celei mai cuprinzătoare. Se pare că, aici, şi întorcându-ne la exemplele din Ambigua 10, Mărturisitorul a încercat interpretarea experiențelor lui Adam și a Evei, dar și a lui Moise, profetul căsătorit, prin lentila tipologiei lui Ilie şi a paradigmei monastice.

Dar ne-am putea întreba, legitim, ce altceva l-ar fi determinat pe Sfântul Maxim să insiste că oamenii trebuie să depășească viaţa animală semnificată de caracteristicile genitale. Insistența sa, am văzut mai sus, nu are nimic de-a face cu natura umană. Probabil că această insistență provine din înțelegerea căderii ca degradare a naturii omenești - semnificată de murdărirea și stricarea chipului luminos al lui Dumnezeu în om $^{94}$ - și prin care trăsăturile genitale au fost afectate. În schimb, descrierea slujirii mântuitoare a lui Hristos, mai jos în Ambigua 41, indică efectele purificării naturii umane de urmele păcatului, inclusiv de proeminența genului în contextul căderii. Acolo, Mărturisitorul arată că, prin paradoxala sa concepție și naștere, mai presus de firea căzută sau, textual, mai

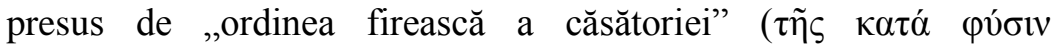

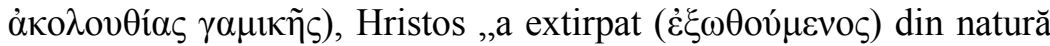

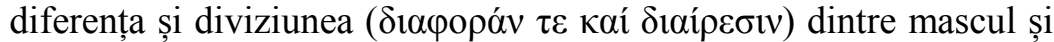
femală",95. Extirparea diferențelor de gen nu trebuie luată însă literal: printre noi și pentru noi, Hristos a trăit ca bărbat, nu ca o ființă asexuată. Eliberarea naturii umane de trăsăturile genului constă în repunerea sa într-o altă condiție decât cea a căderii. Prin aceasta, extirparea diferențelor genitale corespunde „,completei lor

93 On Difficulties, vol. 2:102. Cf. PG 91, 1305C. Vezi și mai târziu (On Difficulties, vol. 2:114-116; PG 91, 1312B-1313B) raporturile dintre categoriile generale și particulare. Cf. ThunBerg, Microcosm and Mediator, 379-381. Aceste concluzii corespund descoperirilor lui Susan Wessel în Scrisoarea 2; vezi „The Theology of Agape in Maximus the Confessor”, în St. Vladimir's Theological Quarterly 55.3 (2011), p. 319-42, mai ales 332-334.

${ }^{94}$ On Difficulties, vol. 2:114. Cf. PG 91, 1312A.

${ }^{95}$ On Difficulties, vol. 2:110. Cf. PG 91, 1309A. 
curățări” prin intermediul virtuții. Folosirea participiului în ambele

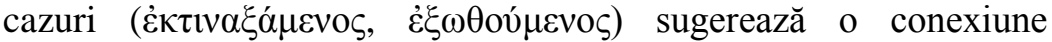
intenționată între cele două pasaje și indică, mai departe, ideea de activitate purificatoare continuă: urmându-L pe Hristos, și sfinții se dedică aceleiași activități.

Ceea ce contează este că, eliberat de condiția căderii, care a acutizat sensul diferențierii genitale, persoanei umane i se dă

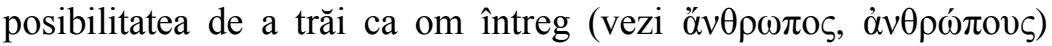
indiferent de gen, unificat întru sine prin viețuirea virtuoasă ${ }^{96}$. Noua condiție, mai presus de gen, este experiența unei umanități integrală, perfectă ${ }^{97}$, corespunzând lui Hristos și care-și află în acesta din urmă sursa și inaugurarea. Sfântul Maxim L-a descris pe Domnul ca „om perfect ( $\tau \varepsilon \dot{\lambda} \lambda \varepsilon 10 \varsigma$ ö $v \theta \rho \omega \pi \circ \varsigma$ ), unul dintre noi, pentru noi și ca noi, posedând identic toate trăsăturile noastre, dar fiind fără păcat" 98 . Astfel, ceea ce contemplăm în Hristos este taina umanității complete, elevată mai presus de diviziune și fragmentare, de asemenea mai presus de tensiunile și discriminările care decurg din acestea, restituită în întregul său. Nu-i de mirare că pasajul se încheie prin parafrazarea zicerii pauline, ,în Hristos Iisus nu sunt

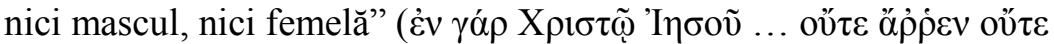
$\theta \tilde{\eta} \lambda v)^{99}$, spre a arăta că realizările lui Hristos devin prin har și ale celor ce cred în El. De altfel, viaţa pământească a Domnului ${ }^{100}$ și condiția paradoxală a Fecioarei Mamă ${ }^{101}$ ilustrează în manieră exemplară noul statut, integral, al umanității. La fel, omul care ,se îmbracă în Hristos" cu haina virtuții transcende biologia deopotrivă și complicațiile, prejudecățile și discriminările care decurg din diviziunea în mascul și femelă - dar fără abolirea trăsăturilor genului ${ }^{102}$.

96 On Difficulties, vol. 2:110, 112-114. Cf. PG 91, 1309B; 1309D-1312A.

97 Vezi CostaCHE, „Living above gender”, p. 278-286.

98 On Difficulties, vol. 2:110. Cf. PG 91, 1309A.

${ }^{99}$ On Difficulties, vol. 2:110-112. Cf. PG 91, 1309AB.

100 On Difficulties, vol. 2:108-114. Cf. PG 91, 1308D-1312B. Vezi ThunBerG, Microcosm and Mediator, p. 377-378.

${ }^{101}$ On Difficulties, vol. 2:118. Cf. PG 91, 1313C.

102 Pentru diverse opinii, vezi Bernardo DE ANGELIS, Natura, persona, libertà: L'antropologia di Massimo il Confessore, Roma, Armando Editore, 2002, p. 
Sfântul Maxim Mărturisitorul despre gen, căsătorie și sfințenie (Ambigua 10 și 41)

Chiar dacă Ambigua 41 nu se referă la căsătorie în mod explicit - cu excepția aluziei din secțiunea a noua, menționată mai sus - putem presupune, justificat, că deși nemaifiind definit prin caracteristicile genitale ale masculinului și ale femininului, cuplul anonim la care capitolul se referă în repetate rânduri nu a încetat să fie o familie. Este vorba despre două ființe umane întregi $(\dot{\alpha} v \theta \rho \omega ́ \pi 0 v \varsigma)^{103}$, un sfânt și o sfântă care până la o vreme au trăit în virtute, mai presus de gen, dar apoi au alunecat spre trăirea pătimașă a sexualității. În Hristos, asemenea cupluri reprimesc harul viețuirii virtuoase, în care tensiunile și inegalităţile cauzate de forma căzută a vieții își pierd puterea. Recunoaștem aici, așadar, elemente pe care le-am întâlnit în Ambigua 10, dar îmbogățite cu noi conotații. Pe această notă, analiza mea progresează către semnificația virtuţii și a sfințeniei în Ambigua 10 și 41.

\section{Căsătoria, monahismul și viața sfântă}

Am văzut deja că, fiind inaugurată de Hristos, starea de integralitate umană semnalată de viețuirea mai presus de trăsăturile genului constă în a trăi virtuos și sfânt. Am mai aflat că, pentru Sfântul Maxim, virtutea reprezintă un factor unificator şi un numitor comun pentru toți oamenii, indiferent de gen şi de circumstanțe sociale precum căsătoria și celibatul. Acestea sunt motivele pentru care virtutea și sfințenia au devenit, în discursul său, importante instrumente pentru explorarea genului și a vieții conjugale. În cele ce urmează voi încerca să adun laolaltă mesajul celor două capitole relevante ale scrierii, Ambigua 10 şi 41, prin aplicarea conceptului evdokimovian al „monahismului interiorizat".

Ambigua 41 se referă de câteva ori și în diverse chipuri la virtute și la viața de sfințenie. Virtutea pare să fie aici, precum în

174-175; COOPER, The Body in St. Maximus the Confessor, p. 221-222; LARCHET, La divinisation de l'homme, p. 589-608.

${ }^{103}$ On Difficulties, vol. 2:114. Cf. PG 91, 1312A. 
scrierea pereche, Răspunsuri către Talasie, modul cel mai potrivit de a folosi lucrurile în funcție de principiile lor constitutive. Spre pildă, „dumnezeiasca virtute” este necesară pentru înfăptuirea primei sinteze în acord cu, ,principiul antecedent” al naturii omenești, rezultatul fiind elevarea ființei umane mai presus de diviziunea genitală. Prin virtute, așadar, în Hristos ori în noua identitate creștină a oamenilor, masculinul şi femininul nu mai contează ${ }^{104}$. Virtutea figurează din nou în cea de-a doua sinteză, în expresia „trăind o viață sfântă, după cum se cuvine” ( $\delta i \grave{\alpha} \tau \tilde{\eta} \zeta$

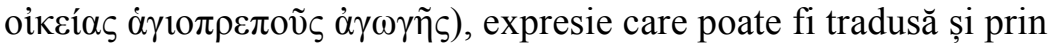
,a trăi o viață pe măsura sfinților"105. Ceva mai târziu întâlnim expresia ,în ce privește virtutea” sau ,potrivit virtuții” ( $\kappa \alpha \tau^{\prime}$

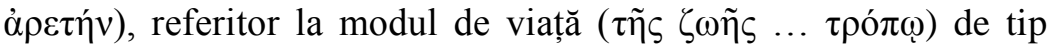

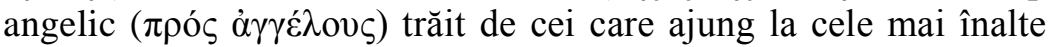
stagii al ascensiunii unificatoare ${ }^{106}$. Mai departe, virtutea conduce

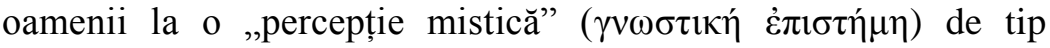
angelic și astfel la ,egalitate (i $\sigma o ́ \tau \eta \tau \alpha)$ cu îngerii în ce privește

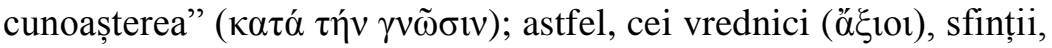
ajung la o formă de percepție a lui Dumnezeu care nu depinde de înțelegere și de interpretare ${ }^{107}$. În sfârșit, virtutea în forma sa cea

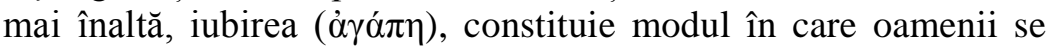
unesc cu Dumnezeu ${ }^{108}$. Virtutea, cunoașterea mistică și iubirea toate fiind caracteristice pentru ,viața trăită pe măsura sfinților”, a celor vrednici, și pentru viețuirea de tip angelic -țintesc spre sfințenie ca factor unificator. Privite împreună, virtutea sau asceza, cunoașterea sau contemplația și iubirea sau unirea descoperă însă, pe lângă dimensiunea spirituală a discursului maximian, ancorarea sa monastică ${ }^{109}$. Într-adevăr, acest tipar triadic evocă maniera în care tradiția ascetică patristică a articulat parcursul vieții duhovnicești cel puțin de la Clement Alexandrinul

104 On Difficulties, vol. 2:104-106, 110-112. Cf. PG 91, 1305CD, 1309B.

105 On Difficulties, vol. 2:106. Cf. PG 91,1305D.

106 On Difficulties, vol. 2:106. Cf. PG 91,1305D.

107 On Difficulties, vol. 2:106-108. Cf. PG 91,1308AB.

108 On Difficulties, vol. 2:108. Cf. PG 91,1308B.

${ }^{109}$ Vezi ThunBerg, Microcosm and Mediator, p. 332-368. 
Sfântul Maxim Mărturisitorul despre gen, căsătorie și sfințenie (Ambigua 10 și 41)

(secolul al doilea) încoace ${ }^{110}$. Mărturii ale acestui tipar se regăsesc la părinții capadocieni și la Evagrie Ponticul (secolul al patrulea), influențând literatura monastică ulterioară, inclusiv gândirea Mărturisitorului ${ }^{111}$. Toate acestea sunt de mare importanță aici.

În prima parte a acestui studiu am aflat că, prin intermediul lui Adam și al Evei, Ambigua 10.28 arată că toate cuplurile sunt chemate la călătoria spirituală, iar în Ambigua 10.31 am văzut că toți oamenii pot ajunge la sfințenie, indiferent de condiția lor socială, precum Ilie cel necăsătorit și precum Moise cel căsătorit. Ceea ce propun este că Ambigua 41 adâncește înțelegerea noastră privind aceste chestiuni. Mai precis, în timp ce Ambigua 10.31 nu continuă discuția după ce afirmă echivalența spirituală a căsătoriei și a celibatului, Ambigua 41 - chiar și nevorbind deschis despre căsătorie - pare să aibă în vedere un cuplu anonim, pe care îl interpretează în lumina experienței ,angelice” și/sau monastice.

Conectarea celor două capitole este posibilă cel puțin datorită interesului - pe care-1 împărtășesc - pentru contemplarea călătoriei virtuoase prin intermediul metaforei ascensiunii duhovnicești. Chiar dacă Ambigua $41 \mathrm{nu}$ vorbește despre un munte, aflăm aici schița unui eveniment al alpinismului de factură mistică. Legătura simbolică a acestui capitol cu muntele din Ambigua 10.31 devine astfel evidentă, făcând posibilă migrația respectivelor imagini între cele două capitole. Așadar, când privim capitolul 41 prin prisma exemplelor din Ambigua 10.31 observăm că diviziunea genitală și viața virtuoasă ale cuplului anonim din Ambigua 41 dezvăluie un chip al lui Moise și al vieții de familie care interiorizează calea lui Ilie și a monahismului. Interpretarea mea se întemeiază pe polisemia imaginilor angelice. Într-adevăr, repetatele mențiuni despre îngeri și despre experiența angelică în Ambigua

110 Vezi Doru Costache, „Christian Gnosis: From Clement the Alexandrian to John Damascene", în The Gnostic World, ed. Garry W. Trompf, Gunner B. Mikkelsen şi Jay Johnston, Routledge Worlds, London and New York, Routledge, 2019, p. 259-270, mai ales 260-261.

111 Costache, „Christian Gnosis”, p. 262-267. 
41 pot fi luate și literal, ca referiri la puterile nevăzute, și ca metafore ale vieții monahale. De la începuturile sale - se știe foarte bine - monahismul s-a referit la propria-i experiență ca „viață angelică”. Mai mult, dat fiind că sfântul Maxim însuşi era monah, prevalența celui de-al doilea sens nu trebuie să ne surprindă. $\mathrm{Nu}$ întâmplător, atunci când se referă la ascensiunea unificatoare prin vocabularul viețuirii îngerești, textul folosește tiparul triadic al virtuții ascetice (primele două sinteze), al cunoaşterii (a treia și a patra sinteză) și al iubirii unificatoare (a cincea sinteză), de factură explicit monastică. Altfel spus, Ambigua 41 privește călătoria spirituală a cuplului anonim prin lentila vieții angelice sau a experienței monastice reprezentată de Ilie. Pasul următor al analizei constă în explorarea semnificației acestor concluzii pentru înțelegerea maximiană a căsătoriei ca viețuire sfântă.

Chiar dacă, de cele mai multe ori, Ambigua 41 discută activitățile unui om (őv $\theta \rho \omega \pi \circ \varsigma)$ în care, din perspectiva capitolului 10.31, putem identifica tipul monastic reprezentat de Ilie, acelaşi cuvânt pare să însemne, cum l-am și tradus pe alocuri, omenirea, nu doar o anumită persoană umană. Mai departe, capitolul 41 vorbește explicit și despre oameni ( $\dot{\alpha} v \theta \rho \omega ́ \pi 0 v \varsigma)$, pe care-i desemnează, de asemenea, ca mascul și femelă, membrii unui cuplu. Am văzut mai sus că, în lumina primei sinteze din cele cinci, acest cuplu era chemat să trăiască mai presus de trăsăturile și de problemele genului, potrivit principiilor virtuții. În Ambigua 10, acest cuplu este identificat când cu strămoșii paradisiaci, când cu Moise și cu soția acestuia, ale căror împliniri duhovnicești nu erau deloc inferioare celor ale monasticului Ilie.

Așadar, deși la un anumit nivel pare să vorbească despre înfăptuirile spirituale ale celor din categoria lui Ilie, monahii, dintrun alt unghi, și la fel de legitim, Ambigua 41 schițează călătoria duhovnicească a unui cuplu sfânt. Urmând calea virtuții, membrii acestui cuplu au ajuns să experieze deplinătatea condiţiei umane, trăind dincolo de fragmentarea şi de tensiunile proprii unei înțelegeri pătimașe a genului. Acest cuplu a adoptat, asemenea familiei lui Moise, aspecte ale experienței monastice. 
Sfântul Maxim Mărturisitorul despre gen, căsătorie și sfințenie (Ambigua 10 și 41)

Este foarte posibil ca, întreprinzând această descriere, Sfântul Maxim să se fi gândit la ceea ce în secolul trecut Evdokimov a numit „monahism interiorizat”. Evdokimov însuși era convins că Mărturisitorul ,a instituit echivalentul vieții monastice pentru credincioșii laici care trăiesc în lume"112 și că, din punctul său de vedere, monahismul poseda ,valoare normativă pentru orice credincios"113. Urmând Sfântului Maxim, Evdokimov a observat că, prin aplicarea unei „dialectici a interiorizării”, ,,valorile nemuritoare ale monahismului... pot fi stabilite ca principii pentru orice viață creștină"114. Această dialectică face posibilă implementarea principiilor vieții monahale fără să impună celor căsătoriţi abandonarea aspectului fizic al iubirii.

Dacă această soluție complexă este consecința directă a evaluării optimiste a căsătoriei de către Evdokimov, în lumina celor discutate de-a lungul acestui studiu se poate afirma că nici pentru Sfântul Maxim experiența „monahismului interiorizat” a unor cupluri sfinte -precum Moise și soția sa - nu presupunea abandonarea cursului normal al iubirii fizice. Într-adevăr, am văzut mai sus că pentru Mărturisitor experința „,monahismului interiorizat" a cuplurilor sfinte se referă la urmarea căii virtuții - un mod de viață mai presus de gen - ca prioritate a vieții. Însă discuțiile de dinainte arată că prin urmarea căii virtuții cuplurile sfinte înfăptuiesc mai mult decât asimilarea unor aspecte ale vieții monastice. Astfel, în Ambigua 41115, Hristos este atât izvorul principiilor constitutive ale ființei umane activate prin virtute, cât și întruparea modului virtuos și sfânt de a trăi. Hristos este, de aceea, numitorul comun al celor căsătoriți și al celor necăsătoriți. În consecință, prin cultivarea virtuții, cuplurile sfinte nu interiorizează doar experiența monahală, ci și harul lui Hristos, virtutea sa pe care experiența monahală o

112 Paul Evdokimov, The Sacrament of Love: The Nuptial Mystery in the Light of the Orthodox Tradition, Crestwood, NY, St. Vladimir's Seminary Press, 2001, p. 82 .

113 The Sacrament of Love, 81.

114 The Sacrament of Love, 83.

115 On Difficulties, vol. 2:108-110. Cf. PG 91, 1308C-1309A. 
interiorizează maximal. Această concluzie corespunde mesajului aflat în Ambigua 10.31a.5 ${ }^{116}$, unde Moise și Ilie, căsătoria și necăsătoria, se bucură în lumina transfiguratoare a Domnului schimbat la față.

Așadar, atât în sine, cât și prin lentila interpretativă a gândirii evdokimoviene, prin integrarea experienței monastice și a vieții conjugale Ambigua 41 oferă o soluție superioară oricăror suspiciuni despre căsătorie ca lipsită de sfințenie și despre sfințenie ca necesitând celibatul sau viața monahală. Devine limpede că prin promovarea unor înalte idealuri despre gen și căsătorie tradiţia patristică nu le relativizează valoarea, cum par a se teme unii cercetători contemporani ${ }^{117}$.

\section{Concluzii}

Provenind de la un autor monastic, pasajele studiate mai sus, din Ambigua 10.28, 10.31a.5 și 41, pot surprinde prin faptul că discută chestiuni legate de gen, sexualitate și viața conjugală. Am văzut că opiniile Sfântului Maxim privind aceste teme își au originea atât în interpretarea unor exemple scripturale precum Adam și Eva ori Moise și soția sa, cât și din convingerea sa filosofică privind importanța activităților virtuoase ale unui cuplu sfânt pentru sporirea unității creației. Am mai descoperit că, vorbind despre Moise cel căsătorit și despre cuplul anonim din Ambigua 41, Mărturisitorul a interpretat experiențele acestora printr-o lentilă asemănătoare conceptului evdokimovian al „monahismului interiorizat”. Procedând astfel, sfântul a construit un pod între viaţa monahală și cea conjugală. Ce a rezultat din această juxtapunere este portretul omului ca sfânt dăruit cu trăsături asemănătoare celor ale lui Hristos, în ale cărui caracteristici fizice nu mai sunt evidente amprentele diviziunii genului proprii lumii păcatului. Interesant de observat este că Sfântul Maxim a descris în acest fel atât membrii cuplurilor sfinte - precum Moise și soția sa,

116 On Difficulties, vol. 1:260. Cf. PG 91,1161D.

117 Vezi CASEY, „The spiritual valency of gender”, p. 174, 177-178. 
Sfântul Maxim Mărturisitorul despre gen, căsătorie și sfințenie (Ambigua 10 și 41)

şi precum cuplul anonim din Ambigua 41 - cât şi celibatarii reprezentați de Ilie, deopotrivă și lumea monahală. Acest procedeu descriptiv indică faptul că el nu împărtășea reținerea mediilor monastice ale timpului său față de viața maritală. Înțelepciunea sa, încă incomplet apreciată de cercetătorii problematicilor de gen și conjugale în lumea bizantină, pune într-o nouă lumină această cultură astăzi percepută ca obsedată de idealuri monastice. Nu în ultimul rând, înțelepciunea Mărturisitorului inspiră dorința de realizare a sfințeniei de-a lungul și de-a latul trupului lui Hristos, chiar dacă mulți aspiranți se vor fi aflând în stagiul ilustrat de strămoșii paradisiac

$\cos 80$

\section{Bibliografie}

1. BEHR, John, The Formation of Christian Theology, Crestwood, NY, St. Vladimir's Seminary Press, 2001, 1:17-70.

2. Blowers, Paul M., „Bodily Inequality, Material Chaos, and the Ethics of Equalization in Maximus the Confessor", în Studia Patristica 42 (2006), p. 51-56.

3. BrubaKer, Leslie / TOUGHER, Shaun (eds.), Approaches to the Byzantine Family, Birmingham Byzantine and Ottoman Studies 14, Farnham, Ashgate, 2013.

4. CASEY, Damien, „The spiritual valency of gender in Byzantine society", in Neil and Garland, Questions of Gender, p. 167-181.

5. CONSTANTINOU, Stavroula, „Family in the Byzantine Greek Legend of Saint Alexios, the Man of God", în Brubaker and Tougher, Approaches to the Byzantine Family, p. 273-284.

6. CONSTANTINOU, Stavroula, „Virginity in danger: Holiness and sexuality in the Life of Mary of Antioch", in $\triangle \Omega P O N$ POАOПOIKIИON: Studies in Honour of Jan Olof Rosenqvist, ed. D. Searby, E. B. Witakowska și J. Heldt, Studia Byzantina Upsaliensia 12, Uppsala, Acta Universitatis Upsaliensis, 2012, p. 123-132.

7. Constas, Nicholas (ed.), Maximos the Confessor: On Difficulties in the Church Fathers: The Ambigua, două volume, Dumbarton Oaks Medieval Library, Cambridge, MA and London, Harvard University Press, 2014. 
8. COOPER, Adam G., ,Saint Maximus on the mystery of marriage and the body: A reconsideration", în Knowing the Purpose of Creation through the Resurrection, ed. Bishop Maxim Vasiljević, Contemporary Christian Thought Series 20, Alhambra, CA, Sebastian Press, 2013, p. 195-221.

9. CoOper, Adam G., The Body in St Maximus the Confessor: Holy Flesh, Wholly Deified, Oxford Early Christian Studies, Oxford, Oxford University Press, 2005.

10. Costache, Doru, „Adam's Holiness in the Alexandrine and Athonite Traditions", în Alexandrian Legacy: A Critical Appraisal, ed. Doru Costache, Philip Kariatlis and Mario Baghos, Newcastle upon Tyne, Cambridge Scholars Publishing, 2015, p. 322-368.

11. Costache, Doru, „Andrew of Crete's Great Canon, Byzantine Hermeneutics, and Genesis 1-3", în Hymns, Homilies and Hermeneutics in Byzantium, ed. Andrew Mellas and Sarah Gador-Whyte, Byzantina Australiensia 25, Leuven and Boston: Brill, 2020, p. 67-85.

12. Costache, Doru, „Byzantine insights into Genesis 1-3: St. Andrew of Crete's Great Canon", în Phronema 24 (2009), p. 35-50.

13. Costache, Doru, „Christian Gnosis: From Clement the Alexandrian to John Damascene", în The Gnostic World, ed. Garry W. Trompf, Gunner B. Mikkelsen și Jay Johnston, Routledge Worlds, London and New York, Routledge, 2019, p. 259-270.

14. Costache, Doru, „Îțelegeri Bizantine: Cartea Facerii, Teologie și Spiritualitate în Canonul cel Mare al Sfântului Andrei Cretanul”, în Imnografia liturgică bizantină: Perspective critice, ed. Alexandru Ioniță, Studia Oecumenica 13, Cluj-Napoca, Presa Universitară Clujeană, 2019, p. 179-216;

15. Costache, Doru, „Living above Gender: Insights from Saint Maximus the Confessor", în Journal of Early Christian Studies 21:2 (2013), p. 261-290.

16. COSTACHE, Doru, „Mapping Reality within the Experience of Holiness", în The Oxford Handbook of Maximus the Confessor, ed. Pauline Allen și Bronwen Neil, Oxford, Oxford University Press, 2015, p. 378-396.

17. Costache, Doru, ,Seeking out the Antecedents of the Maximian Theory of Everything: St. Gregory the Theologian's Oration 38", în Cappadocian Legacy: A Critical Appraisal, ed. Doru Costache 
Sfântul Maxim Mărturisitorul despre gen, căsătorie și sfințenie (Ambigua 10 și 41)

and Philip Kariatlis, Sydney, St. Andrew's Orthodox Press, 2013, p. 225-241.

18. Costache, Doru, „The Transdisciplinary Carats of Patristic Byzantine Tradition", în Transdisciplinary Education, Philosophy, \& Education, ed. Basarab Nicolescu și Atila Ertas, Lubbock, TX, The Academy of Transdisciplinary Learning \& Advanced Studies, 2014, p. 149-165.

19. DE ANGELIS, Bernardo, Natura, persona, libertà: L'antropologia di Massimo il Confessore, Roma, Armando Editore, 2002.

20. EvDOKIMOV, Paul, The Sacrament of Love: The Nuptial Mystery in the Light of the Orthodox Tradition, Crestwood, NY, St. Vladimir's Seminary Press, 2001.

21. KAZHDAN, Alexander et al., A History of Byzantine Literature (650-850), Athens, National Hellenic Research Foundation, 1999.

22. KeLly, Eamon H. R., „From ‘fallen woman' to Theotokos: Music, women's voices and Byzantine narratives of gender identity", în Byzantine Narrative: Papers in Honour of Roger Scott, ed. John Burke et al., Byzantina Australiensia 16, Melbourne, Australian Association for Byzantine Studies, 2006, p. 164-181.

23. LARCHET, Jean-Claude, „Ancestral guilt according to St Maximus the Confessor: A bridge between Eastern and Western conceptions", în Sobornost 20.1 (1998), p. 26-48.

24. LARCHET, Jean-Claude, La divinisation de l'homme selon saint Maxime le Confesseur, Paris, Cerf, 1996.

25. LouTH, Andrew, Maximus the Confessor, The Early Church Fathers, London and New York, Routledge, 1996.

26. MAYER, Wendy, „Constantinopolitan women in Chrysostom's circle”, în Vigiliae Christianae 53.3 (1999), p. 265-288.

27. MCFARLAND, Ian A., „Fleshing out Christ: Maximus the Confessor's Christology in Anthropological Perspective", în St. Vladimir's Theological Quarterly 49.4 (2005), p. 417-436.

28. NEIL, Bronwen / GARLAND, Lynda (eds.), Questions of Gender in Byzantine Society, Farnham, Ashgate, 2013.

29. PONSOYE, Emmanuel, Saint Maxime le Confesseur: Ambigua, Paris și Suresnes, L’ Ancre, 1994.

30. SHERWOOD, Polycarp, „Introduction” to St. Maximus the Confessor: The Ascetic Life and The Four centuries on Charity, Westminster, MD și London: The Newman Press și Longmans, Green and Co., 1955. 
31. SHERwOOD, Polycarp, The Earlier Ambigua of Saint Maximus the Confessor and His Refutation of Origenism, Studia Anselmiana 36, Rome, Herder, 1955.

32. STĂNILOAE, Dumitru, Sfântul Maxim Mărturisitorul: Scrieri, partea întâi, București, Edit. Institutului Biblic și de Misiune al Bisericii Ortodoxe Române, 1983.

33. STANJEVSKIY, Fedor, „Une anthropologie à la base d'une pensée religieuse: L'unité de l'homme dans la théologie de Maxime le Confesseur", în Forum Philosophicum 12 (2007), p. 409-428.

34. THUnBerG, Lars, Microcosm and Mediator: The Theological Anthropology of Maximus the Confessor, Chicago and La Salle, IL, Open Court, 1995.

35. vON BALTHASAR, Hans Urs, Cosmic Liturgy: The Universe According to Maximus the Confessor, trad. Brian E. Daley, San Francisco, CA, Ignatius Press, 2003. 